\title{
Piecing together the Lateglacial advance phases of the Reussgletscher (central Swiss Alps)
}

\author{
Max Boxleitner ${ }^{1}$, Susan Ivy-Ochs ${ }^{2}$, Dagmar Brandova ${ }^{1}$, Marcus Christl $^{2}$, Markus Egli ${ }^{1}$, and \\ Max Maisch ${ }^{1}$ \\ ${ }^{1}$ Department of Geography, University of Zurich, Winterthurerstrasse 190, 8057 Zurich, Switzerland \\ ${ }^{2}$ Laboratory of Ion Beam Physics, ETH Zurich, Otto-Stern-Weg 5, 8093 Zurich, Switzerland
}

Correspondence: Max Boxleitner (max.boxleitner@geo.uzh.ch)

Received: 26 April 2018 - Revised: 29 August 2018 - Accepted: 30 August 2018 - Published: 17 September 2018

\begin{abstract}
Exposure dating has substantially improved our knowledge about glacier advances during the Younger Dryas (YD) and the early Holocene. The glacier development after the Last Glacial Maximum (LGM) and the timing of morphologically evidenced, earlier Lateglacial re-advances is, however, still widely unknown. In this study we used ${ }^{10} \mathrm{Be}$ surface exposure and radiocarbon dating to address these phases and corresponding landforms in the catchment of the former Reussgletscher (central Swiss Alps). We obtained clear indication for moraine deposition prior to the YD. The oldest samples predate the Bølling-Allerød interstadial (>14.6 ka). Morphostratigraphically even older lateral moraines, probably corresponding to terminal positions in the Lake Lucerne, could not be dated conclusively. Due to the geomorphological constraints of the sampling environment, the establishment of a local pre-YD chronology remains a challenge: moraines with adequate numbers of datable boulders were rarely preserved, and age attributions based on few samples are complicated by outliers.
\end{abstract}

\section{1}

\section{Introduction}

Despite the general warming trend during the Lateglacial, glaciers throughout the Alps repeatedly re-advanced in response to various cold phases after the Last Glacial Maximum (LGM). Our understanding of the deglaciation history in many Alpine regions is still fragmentary. Investigating the spatial dimensions and the timing of these glacier stadials is essential to improve our knowledge of the regional climate history, which primarily controls the glaciers' reaction.

Especially for the time period between the LGM and the Younger Dryas chronological constraints of morphologically proven re-advances are very rare (e.g., Ivy-Ochs et al., 2009). As a means for the reconstruction of the past glacier and landscape development, ${ }^{10} \mathrm{Be}$ dating of suitable boulders on moraines enables detecting when these landforms were deposited (e.g., Gosse and Philips, 2001). In the Alps this method has produced valuable results mainly for moraine sequences that were deposited as a response to the Younger Dryas (YD) cooling (12.8-11.7 ka) and during early Holocene glacier advances (e.g., Schimmelpfennig et al., 2012; Schindelwig et al., 2012; Ivy-Ochs, 2015; Moran et al., 2016; Reitner et al., 2016).

In rugged and geomorphologically active regions like the Alps the long-term preservation of sedimentary landforms like moraines is not necessarily given. The overprinting of moraines by erosional and depositional processes and the natural decay of morainic boulders due to weathering and spalling can impede the derivation of the real moraine ages using surface exposure dating (e.g., Reuther et al., 2006). Especially in the densely populated foreland and in the lower parts of the valleys, human impact can also have a negative effect on the preservation of glacigenic landforms (Akçar et al., 2011). Due to the building of settlements and infrastructure and the widespread usage of erratic boulders as construction material, an adequate number of datable boulders is rare, even on the surface of well-preserved moraines. These difficulties have so far hampered the introduction of a conclusive, numerically dated chronology of the Lateglacial glacier development prior to the YD. With this study we try to extend our knowledge about the glacier history in the central Swiss Alps and address key sites in the catchment of the 


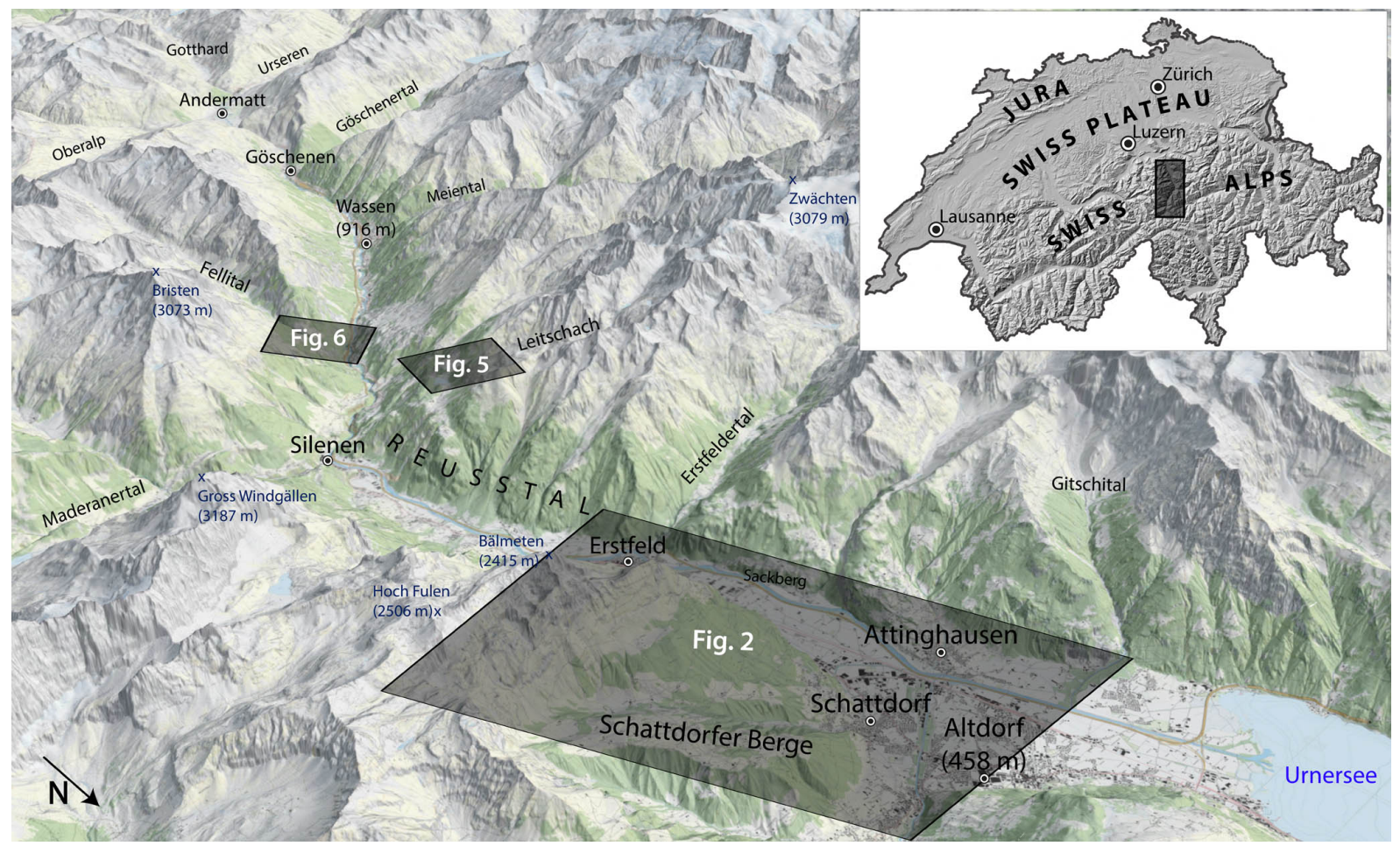

Figure 1. Overview map of the Reusstal between Altdorf and Andermatt (view to the southwest). Inset map shows the location within Switzerland. The black boxes show the outlines of the maps of the different research sites (Figs. 2, 5 and 6). Reproduced by permission of swisstopo (BA18043).

former Reussgletscher to narrow down the timing of glacier advances during the early and middle Lateglacial $(\sim 19$ $12.8 \mathrm{ka})$.

\section{Study site}

The study area lies in the northern Swiss Alps in the canton of Uri (Fig. 1). The investigated section of the $\mathrm{N}-\mathrm{S}$-oriented Reusstal (Reuss Valley) extends for ca. $20 \mathrm{~km}$ between the villages of Altdorf (438 ma.s.l.) and Wassen ( $916 \mathrm{~m}$ a.s.l.). Climatically the research area is characterized by mean monthly temperatures between $0.7^{\circ} \mathrm{C}$ in January and $18.1^{\circ} \mathrm{C}$ in July (Altdorf station; reference period: 1864-2018; data provided by MeteoSwiss). Some of the investigated sites lie almost $1000 \mathrm{~m}$ higher; temperatures at these altitudes can be expected to be on average around $6-7^{\circ} \mathrm{C}$ lower. The average annual precipitation in Altdorf is $1203 \mathrm{~mm}$ (reference period: 1864-2017).

Geologically, the investigated part of the Reusstal belongs to the Infrahelvetikum: within the study area this tectonic unit comprises the crystalline Aar Massif in the southern section and an autochthonous Mesozoic-Tertiary sedimentary cover including the northern Helvetic flysch in the northern area (Spillmann et al., 2011). In the region around the Fellital the Aar Massif mainly consists of granites, while in the section north, up to Erstfeld, gneiss predominates. North and east of Erstfeld the boundary between the crystalline rocks of the Aar Massif and the autochthonous sediments and North Helvetic flysch can be found (Fig. 2) (Labhart and Pfiffner, 2011). The peaks of the adjoining mountain ranges to the north, in particular the Hoch Fulen unit (Fig. 1), consist mainly of limestone. In the context of our study this boundary is important, because ${ }^{10} \mathrm{Be}$ dating can only be used for rock types containing quartz.

Glacial landforms and preserved moraine stages in the study area have already been described and interpreted in previous studies, but without absolute age constraints (Hantke, 1980, and references therein; Renner, 1982; Spillmann et al., 2011). Recent studies in the area of the Göschenertal (Boxleitner et al., 2017) and the Meiental (Boxleitner et al., unpublished data) have shown that the Reusstal was widely ice free during the YD; glaciers that formerly contributed to the Reussgletscher were already confined to the side valleys.

The Reusstal has seen substantial remodeling due to the construction of important railway lines and roads. As one of the main traffic axes in the Alps, the Reusstal connects the Swiss foreland via the Gotthard Pass and Tunnel with southern Switzerland. Glacigenic landforms on the floor of this narrow valley have only scarcely been preserved. Our study therefore investigates key sites along the valley flanks with a focus on potentially old (pre-YD) glacigenic landforms. Fur- 
Table 1. Sample properties and calculated exposure ages. Latitude and longitude are in WGS84 coordinates. Shielding correction includes the effects caused by mountain topography, dip and strike of the various boulder surfaces. Rock density is $2.7 \mathrm{~g} \mathrm{~cm}^{-3}$ throughout. The applied erosion rate is $1 \mathrm{~mm} \mathrm{kyr}^{-1}$. The samples are gneiss (gn) or granite (gr). Input data used for the online exposure age calculation (http://hess.ess.washington.edu/math/, April 2018) can be found in the Supplement.

\begin{tabular}{|c|c|c|c|c|c|c|c|c|c|c|c|c|}
\hline No. & Sample name & $\begin{array}{l}\text { Lat. } \\
\text { (DD) }\end{array}$ & $\begin{array}{l}\text { Long. } \\
\text { (DD) }\end{array}$ & $\begin{array}{l}\text { Elevation } \\
\text { (m a.s.l.) }\end{array}$ & Lithology & $\begin{array}{l}\text { Thickness } \\
(\mathrm{cm})\end{array}$ & $\begin{array}{l}\text { Shielding } \\
\text { factor }\end{array}$ & $\begin{array}{l}\text { Quartz } \\
\text { (g) }\end{array}$ & $\begin{array}{l}\text { Carrier } \\
(\mathrm{mg})\end{array}$ & $\begin{array}{l}{ }^{10} \mathrm{Be}^{\mathrm{a}} \\
\left(10^{3} \text { atoms g }{ }^{-1}\right)\end{array}$ & $\begin{array}{l}\text { Exposure age } \\
\text { (a) }\end{array}$ & $\begin{array}{l}\text { Snow correction } \\
\text { (a) }\end{array}$ \\
\hline 1 & Fellital 1 & 46.7362 & 8.64709 & 1147 & $\mathrm{gr}$ & 2.5 & 0.936 & 30.52 & 0.324 & $108.95 \pm 5.80$ & $11240 \pm 610$ & \multirow{9}{*}{$13290 \pm 1930$} \\
\hline 2 & Fellital 2 & 46.7413 & 8.64054 & 731 & $\mathrm{gr}$ & 3.5 & 0.930 & 31.41 & 0.340 & $45.85 \pm 3.39$ & $6700 \pm 500$ & \\
\hline 3 & Arnisee 1 & 46.7713 & 8.64048 & 1383 & gn & 2.5 & 0.945 & 31.12 & 0.343 & $155.82 \pm 8.09$ & $13250 \pm 700$ & \\
\hline 4 & Arnisee 2 & 46.7713 & 8.63882 & 1406 & gn & 3 & 0.953 & 30.81 & 0.344 & $140.89 \pm 8.54$ & $11700 \pm 720$ & \\
\hline 5 & Arnisee 3 & 46.7706 & 8.63839 & 1386 & gn & 4 & 0.960 & 28.42 & 0.340 & $172.25 \pm 10.82$ & $14600 \pm 930$ & \\
\hline 6 & Arnisee 4 & 46.7707 & 8.63821 & 1403 & gn & 5 & 0.949 & 28.23 & 0.344 & $156.74 \pm 7.49$ & $13350 \pm 650$ & \\
\hline 7 & Erstfeld Sackberg ${ }^{b}$ & 46.8323 & 8.63430 & 580 & gr & 2 & 0.955 & 33.45 & 0.343 & $82.13 \pm 11.74$ & $13200 \pm 1910$ & \\
\hline 8 & Schattdorf 1 & 46.856 & 8.68148 & 1223 & gn & 3 & 0.988 & 28.98 & 0.346 & $140.74 \pm 8.68$ & $13020 \pm 820$ & \\
\hline 9 & Schattdorf 2 & 46.8546 & 8.69288 & 1393 & gn & 1.5 & 0.986 & 30.74 & 0.339 & $77.32 \pm 5.89$ & $6150 \pm 470$ & \\
\hline
\end{tabular}

a AMS measurements errors are at the $1 \sigma$ level

b Bedrock sample.

ther, uninvestigated, stratigraphically younger moraines can be found, e.g., in the Maderanertal (Fig. 1).

The stratigraphically oldest moraines were studied in the area of the Schattdorfer Berge. Here a whole set of moraines indicates both a previous glaciation of the main valley and subsequent local glacier advances. In the lower part of the Reusstal we investigated the zone west of Erstfeld, where we dated a sample from glacially polished bedrock (Erstfeld Sackberg). The next higher study site is located at the confluence of the Reusstal and the Leitschach. Here we examined two distinct moraine generations: one, confined to the Leitschach valley, witnesses a local glacier advance, whereas the other, older moraine indicates a glacier occupying the main valley. In addition to the boulder samples, we took a peat core from an adjoining bog. The southernmost study site is located in the area where the Fellital enters the Reusstal. Here we investigated two moraines of the former Fellitalgletscher.

\section{Methods}

To assess the Lateglacial development of the Reussgletscher and its tributaries, we analyzed topographical and geological maps, as well as digital elevation models, and studied the overall geomorphologic setting with a focus on moraines and other glacigenic landforms directly in the field. To constrain the time of formation of the observed landforms, we use both surface exposure and radiocarbon dating.

\section{1 ${ }^{10} \mathrm{Be}$ exposure dating}

Based on standard sampling criteria (see Gosse and Philips, 2001; Ivy-Ochs and Kober, 2008), we collected 11 samples from morainic boulders and one bedrock sample for exposure dating. The geomorphological evaluation and the careful selection of every boulder are crucial for the reliability of the dating results. Often, boulders are not optimal, or only one boulder on a moraine fits the tight criteria for surface expo- sure dating (e.g., being large enough). Where enough suitable boulders are present, sampling several $(\sim 3-5)$ boulders per moraine can increase the trustworthiness of the age attribution (Putkonen and Swanson, 2003; Ivy-Ochs and Kober, 2008). But relying on one boulder that meets all geomorphologic criteria can be more promising and effective than dating mediocre samples (Ivy-Ochs et al., 2007).

The rock material was obtained with a battery-powered saw, hammer and chisel. The lithology of the samples was gneiss and granite. The chemical isolation of the ${ }^{10} \mathrm{Be}$ followed in-house standard procedures, mainly based on the work of Kohl and Nishiizumi (1992) and Ivy-Ochs et al. (1996). Initially the samples were crushed and sieved (0.25$0.6 \mathrm{~mm}$ ). Then organic and calcareous contaminations were removed with aqua regia (a mixture of nitric and hydrochloric acid). After a $1 \mathrm{~h}$ treatment with $0.4 \%$ hydrofluoric acid (HF) we used a froth floatation system to physically separate micas and feldspar components from the sample. To obtain pure quartz, the samples were treated with $4 \% \mathrm{HF}$. Subsequently we added a ${ }^{9} \mathrm{Be}$ carrier solution to the dried quartz and dissolved the samples with $40 \% \mathrm{HF}$. Afterwards Be was isolated using ion exchange resins and selective $\mathrm{pH}$ precipitation techniques (von Blanckenburg et al., 1996). The ${ }^{10} \mathrm{Be} /{ }^{9} \mathrm{Be}$ ratios were measured with the TANDY mass spectrometer of the ETH Laboratory of Ion Beam Physics against the ${ }^{10} \mathrm{Be}$ standard $\mathrm{S} 2007 \mathrm{~N}$ with a nominal value of ${ }^{10} \mathrm{Be} /{ }^{9} \mathrm{Be}=28.1 \times 10^{-12}$ (Kubik and Christl, 2010; Christl et al., 2013). $\mathrm{S} 2007 \mathrm{~N}$ has been calibrated to the ${ }^{10} \mathrm{Be}$ standard ICN 01-5-1, which has a nominal ${ }^{10} \mathrm{Be} /{ }^{9} \mathrm{Be}$ value of $2.709 \times$ $10^{-11}$ (Nishiizumi et al., 2007). Stated ${ }^{10} \mathrm{Be} /{ }^{9} \mathrm{Be}$ ratios include analytical uncertainties of the accelerator mass spectrometry (AMS) measurement (errors: $1 \sigma$ level). The exposure ages were calculated from the blank-corrected measurements (blank value: $\left.(0.007 \pm 0.0021) \times 10^{-12}\right)$ using the online tool CRONUS-Earth (Balco et al., 2008) (http://hess.ess. washington.edu, last access: April 2018) with a ${ }^{10} \mathrm{Be}$ half-life of $1.387 \pm 0.012 \mathrm{Myr}$ (Chmeleff et al., 2010; Korschinek et al., 2010) and the northeastern North America (NENA) ${ }^{10} \mathrm{Be}$ 
production rate of $3.87 \pm 0.19{ }^{10} \mathrm{Be}$ atoms gram $\mathrm{qtz}^{-1} \mathrm{yr}^{-1}$ (Balco et al., 2009). The calculation of a local ${ }^{10} \mathrm{Be}$ production rate at the Chironico landside in the southern Swiss Alps has shown that this production rate is very suitable for the Alps (Claude et al., 2014). Moreover it matches well with recently calculated global ${ }^{10} \mathrm{Be}$ production rates (Heyman, 2014; Borchers et al., 2016). Exposure ages were scaled to the geographical location according to the scheme of Lal (1991) and Stone (2000) and corrected for the sample geometry. The effect of geometric shielding by surrounding mountains on the amount of cosmic radiation reaching each sample was calculated on the basis of field data with the online geometric-shielding calculator CRONUS (http://hess. ess.washington.edu, last access: April 2018). We applied an erosion rate of $1 \mathrm{~mm} \mathrm{kyr}^{-1}$ (André, 2002) to determine the exposure ages.

In contrast to boulder samples, exposure ages from bedrock samples are normally corrected for the shielding influence of snow. A snow correction was performed for the single bedrock sample Erstfeld Sackberg, in accordance with Gosse and Philips (2001), on the basis of a snow density of $0.3 \mathrm{~g} \mathrm{~cm}^{-3}$ and an attenuation length of $109 \mathrm{~g} \mathrm{~cm}^{-2}$ (Zweck et al., 2013; Delunel et al., 2014). For the calculation we assumed a closed snow cover of $10 \mathrm{~cm}$ over 3 months. We base this assumption on data from the MeteoSwiss station in Altdorf ( $438 \mathrm{~m}$ a.s.l.). The sample location lies approximately $150 \mathrm{~m}$ higher. We therefore used slightly higher snow cover values. The snow cover throughout the Lateglacial and Holocene was most likely very variable. The snow correction factor (0.993) is therefore connected to considerable uncertainty. Because of the low snow cover at the sample altitude, the derived snow-corrected exposure age is only negligibly older than the uncorrected exposure age (ca. 100 a).

In the discussion we therefore use the exposure age without snow correction.

\subsection{Radiocarbon dating of peat}

The peat bog northeast of the Arnisee could only start to develop after the Reussgletscher had vanished from the area. Dating the onset of the bog formation therefore provides a minimum age for the ice retreat. We used avalanche probes to detect the thickest and potentially oldest point of the bog and subsequently retrieved cores with a handheld peat drill. For dating, we extracted peat fragments from the lowermost layer $(1 \mathrm{~cm})$, directly above the inorganic sediments (depth $475 \mathrm{~cm}$ ) that were deposited prior to the bog formation. The peat fragments were cleaned using an acid-alkaliacid (AAA) treatment and heated under vacuum in quartz tubes with $\mathrm{CuO}$ (oxygen source). The tubes were then evacuated again, sealed and heated in the oven at $900{ }^{\circ} \mathrm{C}$ to obtain $\mathrm{CO}_{2}$. The $\mathrm{CO}_{2}$ of the combusted sample was mixed with $\mathrm{H}_{2}$ $(1: 2.5)$ and catalytically reduced over iron powder at $535^{\circ} \mathrm{C}$ to elemental carbon (graphite). After reduction, the mixture was pressed into a target and the carbon ratio was measured by AMS using the $0.2 \mathrm{MV}$ radiocarbon dating facility (MICADAS) of the ETH Laboratory of Ion Beam Physics. The calendar age was calibrated using OxCal 4.3 (Bronk Ramsey, 2009), based on the IntCal 13 calibration curve (Reimer et al., 2013). The calibrated age is given in the $2 \sigma$ range.

\section{Dating results and interpretation}

We determined the exposure ages of eight boulders and one bedrock sample (Table 1). Three more boulder samples could not be dated because of too-low quartz content. The detailed description of the sampling sites follows the Reusstal from the north towards the inner Alpine region.

\subsection{Schattdorfer Berge}

The Schattdorfer Berge area is marked by a very interesting glacial geomorphology (Figs. 2 and 3): in the northern part a series of five right-lateral moraines (I-V) at altitudes between 1000 and $1300 \mathrm{~m}$ is preserved. Their position and direction indicate that the moraines were deposited by a more than $1000 \mathrm{~m}$ thick main valley glacier (Spillmann et al., 2011). Crystalline erratics undoubtedly prove that the Reussgletscher deposited these moraines, as the mountain range of the Hoch Fulen unit directly to the south is built of limestone (Labhart and Pfiffner, 2011). Corresponding terminal positions are most probably subaquatic glacigenic landforms found at the bottom of Lake Lucerne. A clear assignment to the suggested moraine stages in the lake (from distal to proximal: Meggen, Kehrsiten (Chrüztrichter), Nase (Vitznau) and Chindli (Gersau); Penck and Brückner, 1909; Hilbe et al., 2011) has to remain open at this point. To address the depositional ages, we took five rock samples from different moraines and ice margin positions at the Schattdorfer Berge site. The three samples Studenbergliwald 1-3 did not contain enough quartz to complete the chemical processing. The two samples Schattdorf 1 and 2 were dated to $13020 \pm 820 \mathrm{a}$ and $6150 \pm 470$ a, respectively. Considering the stratigraphic position within the Reussgletscher system, both samples seem far too young, also given the fact that YD-aged moraines in the Reuss catchment have been described much further up-valley, i.e., at the entrance to the Göschenertal (Fig. 1) (Boxleitner et al., 2017). Considering the high and therefore potentially old sampling site of the sample Schattdorf 2, this boulder was most likely exhumed well after its deposition at the former ice margin. An explanation for the too-young age of the sample Schattdorf 1 is not that obvious. A degradation of the landform due to the construction of the small chapel on top of the moraines and hence a later exhumation of the sampled boulder is a possible but unverifiable reason for this result (Fig. 3). In the end, the timing of the deposition of these moraines remains unclear despite our dating efforts.

In the southern part of the Schattdorfer Berge a series of moraines (I-III), including a well-preserved terminal moraine (Figs. 2 and 3), witnesses repeated advances of 


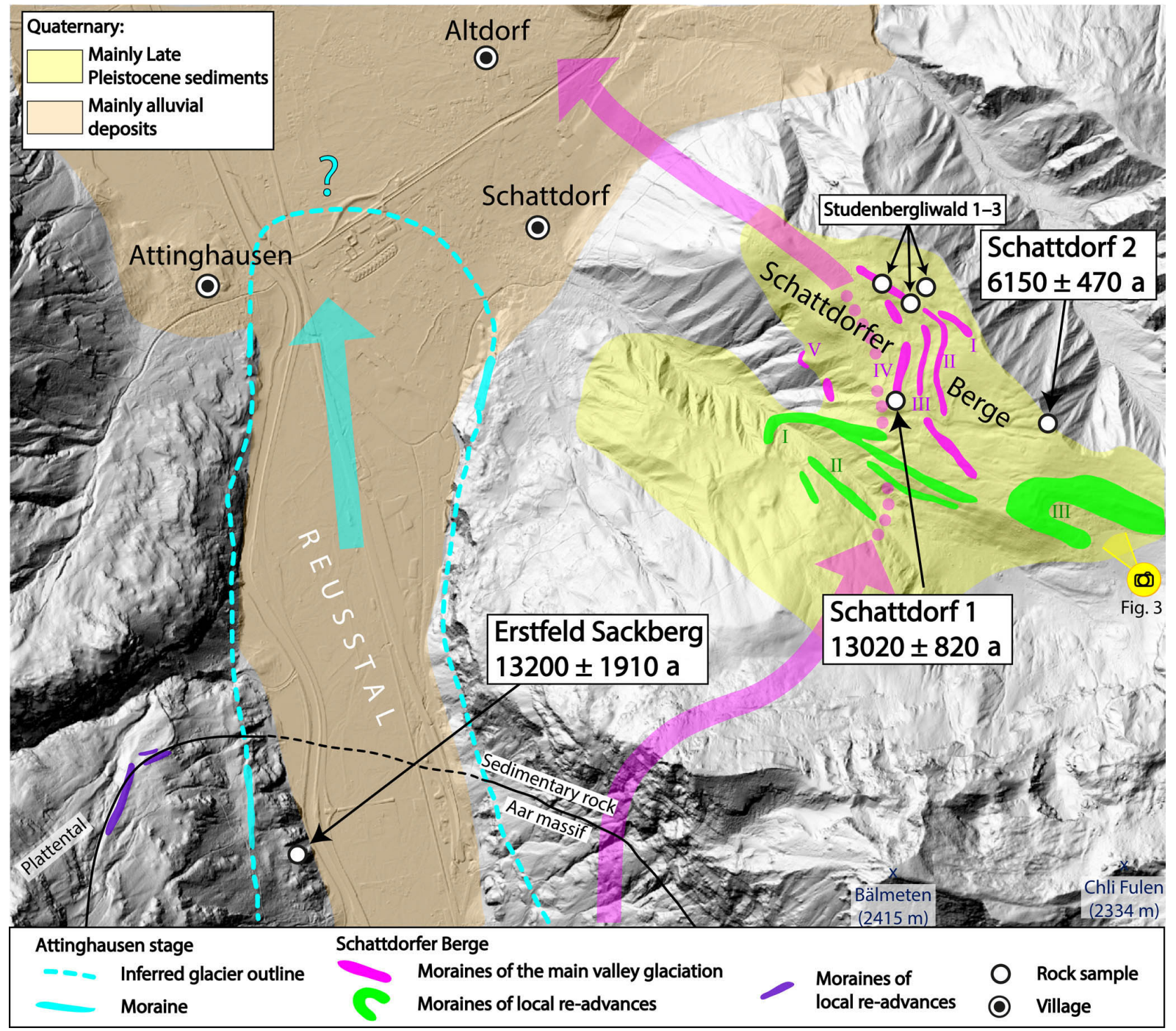

Figure 2. Map of the area of Erstfeld and the Schattdorfer Berge. Colored arrows indicate glacier flow direction of the Reussgletscher during the time of corresponding till deposition. Boulders Studenbergliwald 1-3 could not be dated because of too-low quartz content. The camera symbol shows the perspective seen in Fig. 3. Reproduced by permission of swisstopo (BA18043).

a local glacier originating from the northern slopes of the Hoch Fulen and the Bälmeten. During the main valley glaciation, the Hoch Fulen-Bälmeten glacier was a tributary to the Reussgletscher. After a pronounced lowering of the ice surface in the Reusstal, this glacier re-advanced on a local scale, crosscut the lateral moraines of the former Reussgletscher and produced moraines that are, based on their stratigraphic position, indisputably younger than the ones right to the north. In addition to the clearly different morphostratigraphic positions, the two moraine generations can also be distinguished on the basis of the rock type (crystalline versus limestone). Despite the presence of large blocks, we did not take any samples from the moraines of these local moraines, because the quartz-free sedimentary rocks of this area cannot be dated using ${ }^{10} \mathrm{Be}$.

\subsection{Erstfeld Sackberg}

Between Erstfeld and Attinghausen (Fig. 2) a clearly discernible former ice margin on the orographically left side, dipping towards the valley floor, indicates a glacier terminal position in the area of Attinghausen (Attinghausen stage; Hantke, 1980, and references therein; Renner, 1982; Renner in Spillmann et al., 2011). Additional moraines that are attributed to the Attinghausen stage can be found south of the village and less clearly on the other side of the valley in the southern part of Schattdorf. Probably due to a combination of natural erosion and human activity, the terminal moraine has not been preserved. Still, on the basis of the dipping ice margin and the low-lying preserved moraine traces, the location of the former glacier terminus can be well approximated, even if the exact position remains ambiguous. Moraines of a 


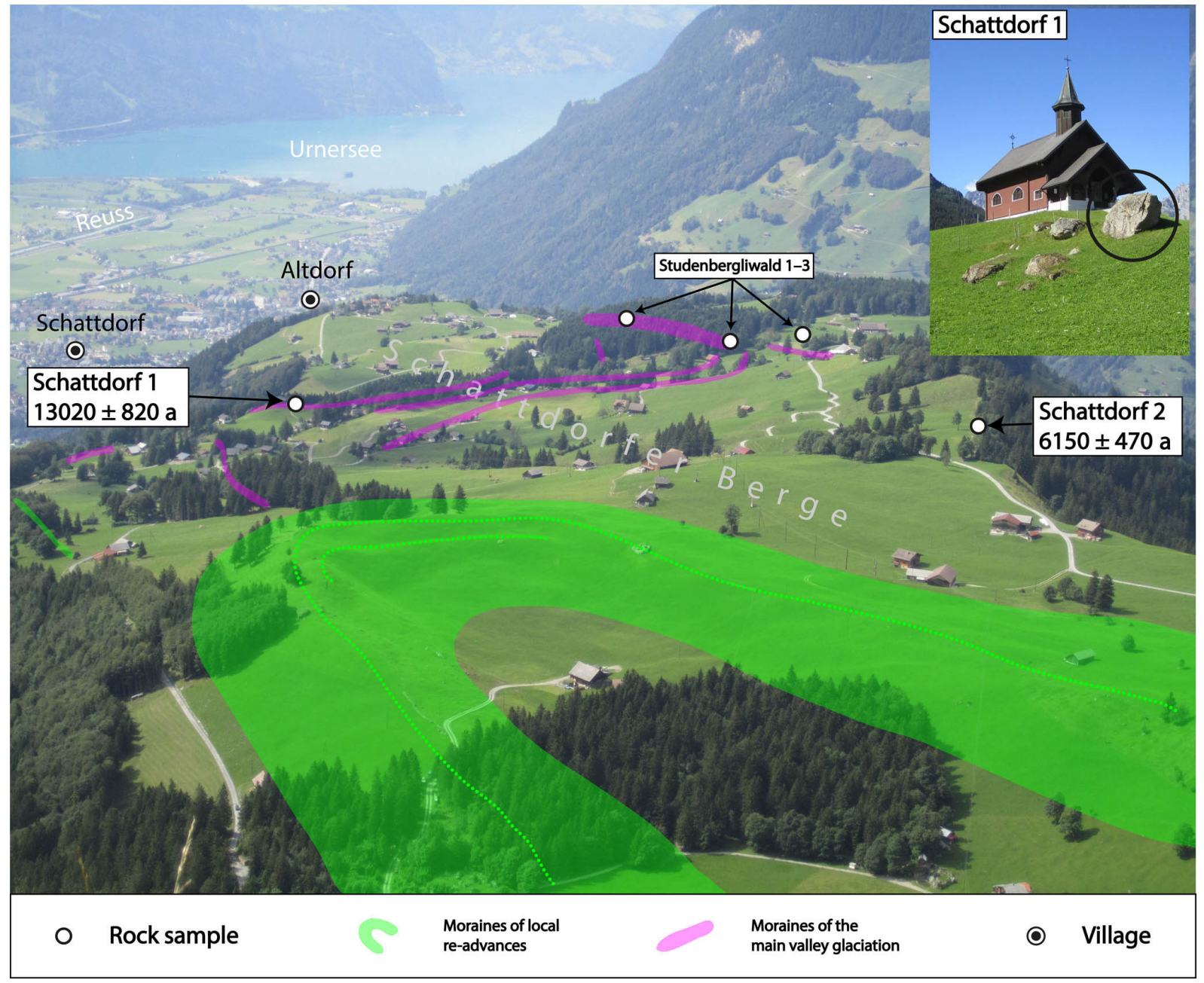

Figure 3. Photo of the moraines in the area of the Schattdorfer Berge. Large boulders on the moraine in the foreground consist of limestone and can therefore not be dated using ${ }^{10} \mathrm{Be}$ dating.

local glacier from the Plattental that were probably deposited in parallel and almost reached the main valley glacier can be found northwest above the clear left-lateral ice margin. We did not find any datable boulders on the moraines of the Attinghausen stage. Instead, we sampled the glacially polished bedrock outcropping in the area of Erstfeld Sackberg, which was dated to $13200 \pm 1910 \mathrm{a}$. Because this site lies inside the outlines of the Attinghausen stage, the derived age represents a minimum age for this situation. But owing to the relatively high measurement uncertainty of this single exposure age, a conclusive dating or stadial attribution of the Attinghausen stage is not feasible.

\subsection{Leitschach-Arnisee}

Approximately $11 \mathrm{~km}$ up-valley, the Leitschach meets the Reusstal (Fig. 4). In the lower part of this side valley, distinct moraines of four different glacier stages can be discerned (Fig. 5). The inner two stages representing local glacier advances could not be dated, because suitable boulders were missing. The next older stage, indicating a local glacier terminal position close to the mouth of the side valley, consists of very clear moraines with large boulders. We have dated two samples on the left-lateral moraine: Ar-

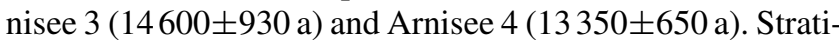
graphically older, the fourth preserved glacier stage is represented by a left-lateral moraine bending in the direction of the Reusstal, which implies a connection to the former Reussgletscher filling up the main valley to this altitude. The corresponding frontal position of the Reussgletscher cannot be conclusively inferred, but a connection with the Attinghausen stage appears to be the most plausible scenario. The two dated samples Arnisee 1 and Arnisee 2 produced exposure ages of $13250 \pm 700 \mathrm{a}$ and $11700 \pm 720 \mathrm{a}$. In view of their morphostratigraphic position, these dates should be older than the samples Arnisee 3 and 4. The obtained exposure ages indicate a logically impossible age inversion and do not reflect the local stratigraphic sequence. Presumably this 
Table 2. Radiocarbon ages.

\begin{tabular}{llllllllll}
\hline Sample & $\begin{array}{l}\text { Lat. } \\
\text { (DD) }\end{array}$ & $\begin{array}{l}\text { Long. } \\
\text { (DD) }\end{array}$ & $\begin{array}{l}\text { Elevation } \\
\text { (m a.s.1.) }\end{array}$ & Code & Material & Treatment & $\begin{array}{l}{ }^{14} \mathrm{C} \text { Age } \\
\text { (a before 1950) }\end{array}$ & $\begin{array}{l}\text { Error } \\
(\text { a) }\end{array}$ & $\begin{array}{l}\text { cal }{ }^{14} \mathrm{C} \text { age } \\
(\mathrm{Cal} \text { BP; } 2 \sigma \text { range })\end{array}$ \\
\hline Arnisee bog & 46.77211 & 8.64713 & 1373 & UZ-6424 & peat & AAA & 12527 & 49 & $15108-14416$ \\
\hline
\end{tabular}

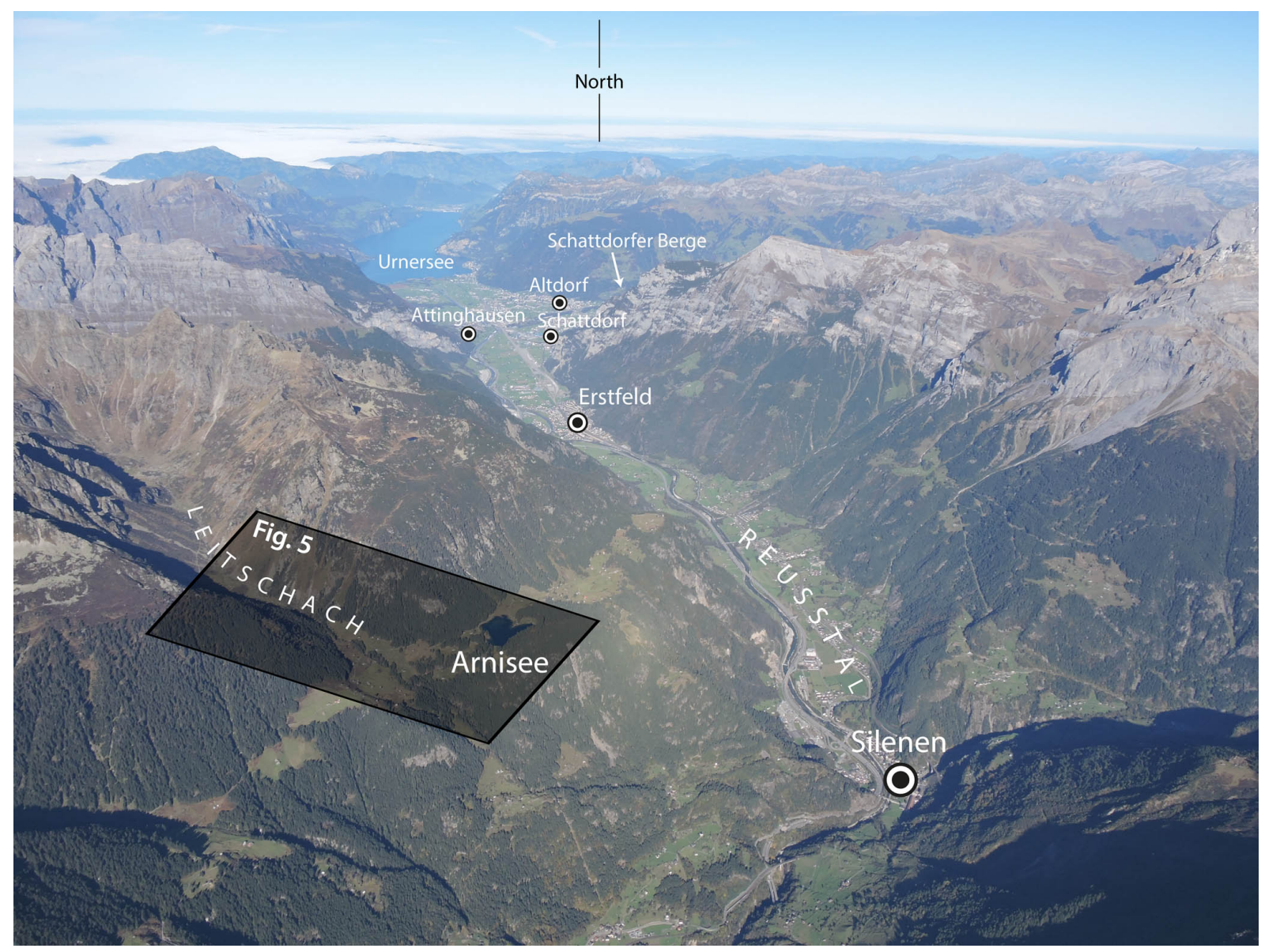

Figure 4. Aerial photo of the Reusstal with the outline of the study site Leitschach-Arnisee (Fig. 5). (Photograph $@$ C Christine Levy Rothenbühler, 16 October 2016)

moraine degraded over time, so that the boulders were exhumed after the deposition of the moraine, which leads to an underestimation of the real moraine age. This interpretation is supported by the radiocarbon date from the peat bog east of the Arnisee: the transition from inorganic sediment to peat and therefore the starting point for the development of the peat bog was dated to $15108-14416 \mathrm{cal}$ a BP. The starting point of the bog development can therefore most likely be attributed to the Bølling interstadial (14.6-14.0 ka) (Table 2). This date represents a minimum age for the disappearance of the glacier from this location. The moraine of the local Leitschachfirn joining the Reussgletscher in the main valley thus has to be older. Accordingly, a pre-Bølling-Allerød age can be inferred for the corresponding glacier terminal position in the Reusstal, presumably lying in the area of Atting- hausen. This interpretation would also be affirmed by the age of the sample Erstfeld Sackberg (within its high measurement uncertainties).

\subsection{Fellital}

North of Wassen, where the Fellital meets the Reusstal, three pronounced right-lateral moraines and one left-lateral moraine document a local glacier advance to a nearby terminal position (Fig. 6). Remnants of a left-lateral moraine belonging to this advance can also be found up-valley at the site Felliberg. To constrain the age of this glacier outline, we dated two boulders. Sample Fellital 1 yielded an age of $11240 \pm 610$ a. Fellital 2 was dated to $6700 \pm 500$ a. In view of the stratigraphic position inside the Reusstal, sample Felli- 


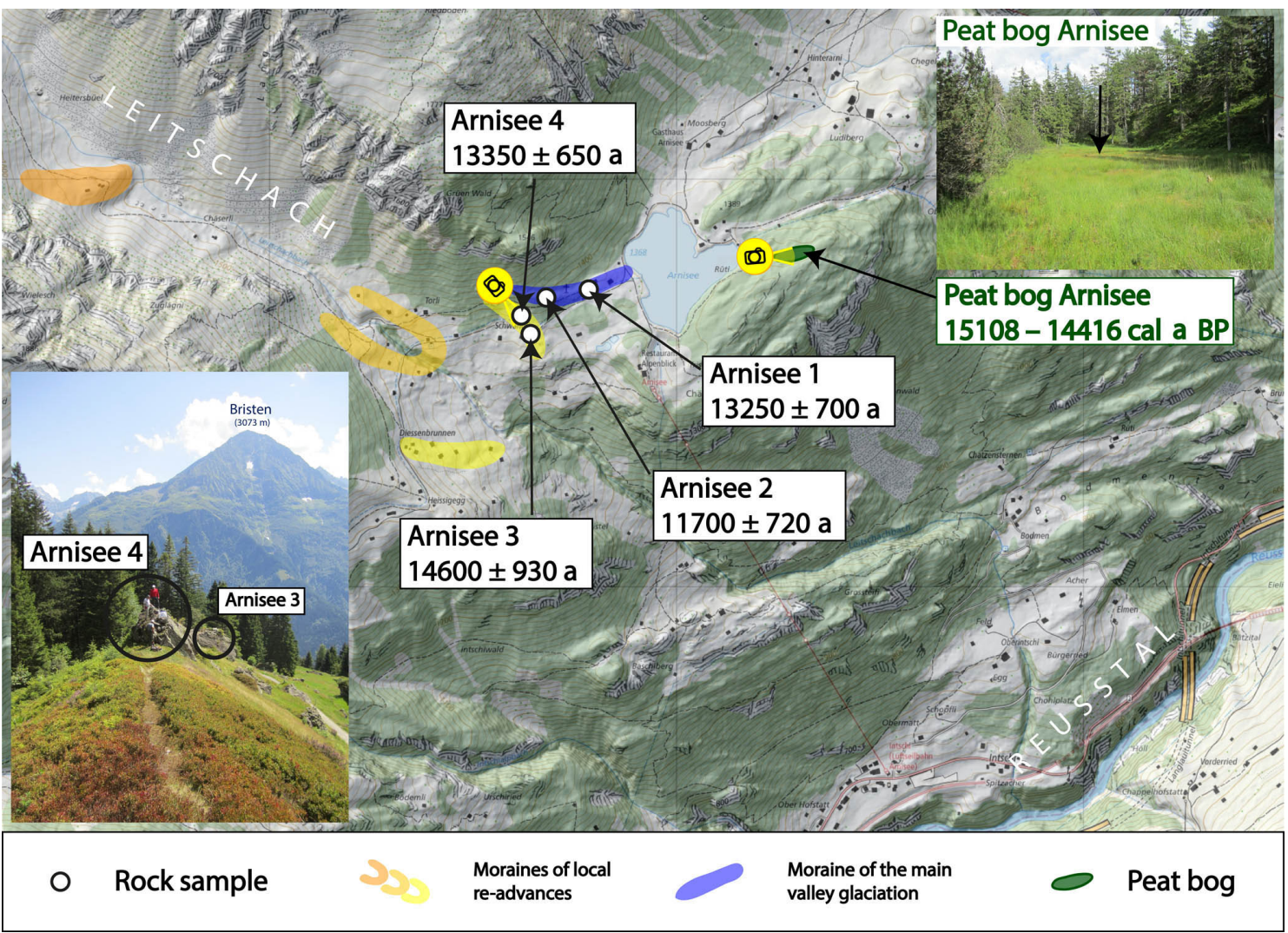

Figure 5. Map and photos of the moraines and the bog at the Leitschach-Arnisee sample sites. The camera symbols show the perspective seen in the photographs. Reproduced by permission of swisstopo (BA18043).

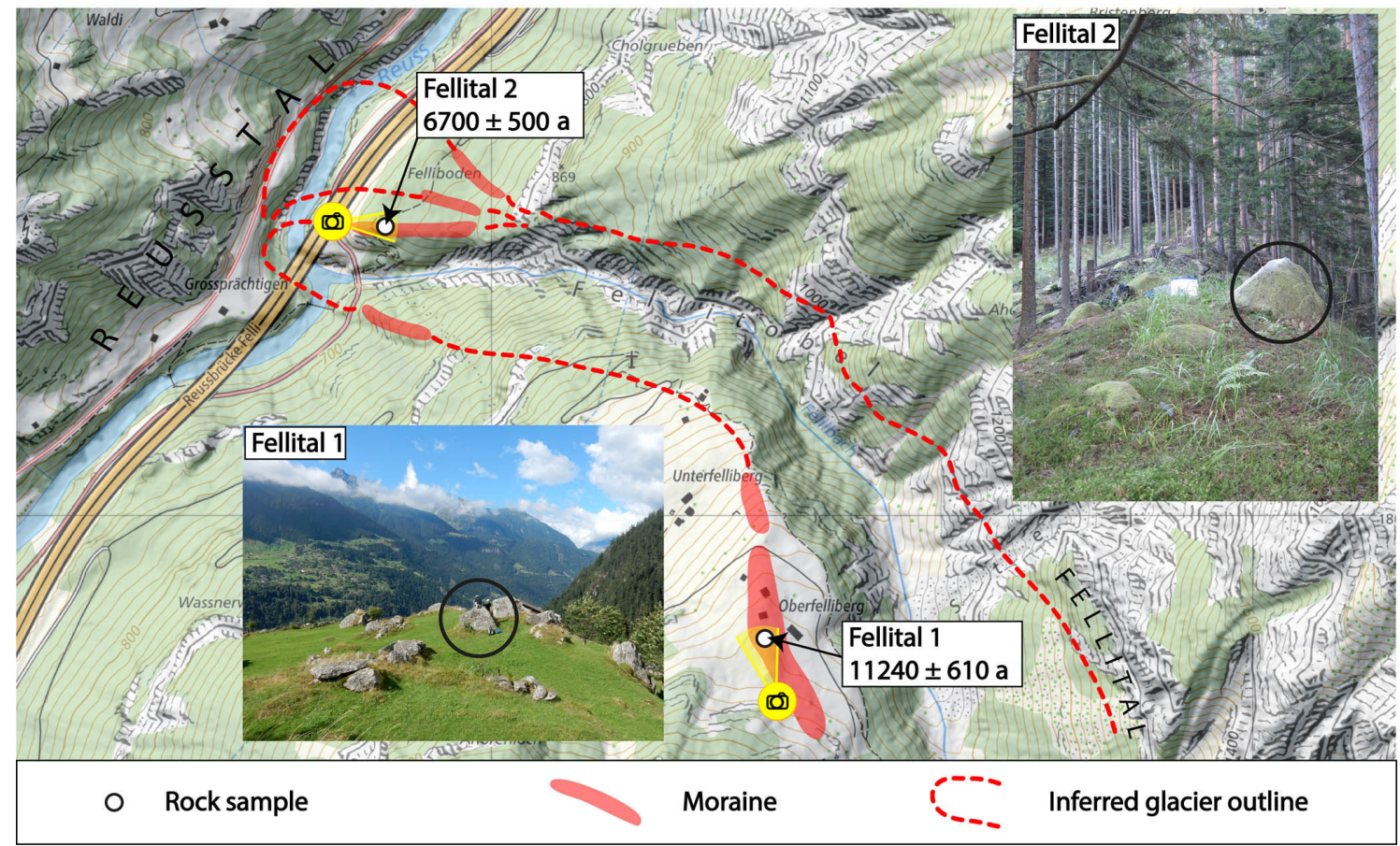

Figure 6. Map and photos of the moraines at the Fellital sample site. The camera symbols show the perspective seen in the photographs. Reproduced by permission of swisstopo (BA18043). 
tal 1 could represent a reasonable deposition age. Within the measurement uncertainties this age can be attributed to the late phase of the YD. A local glacier terminal position in the nearby village of Göschenen has recently been dated to the YD (Boxleitner et al., 2017); a correlation of these advances therefore appears possible. Nevertheless, on the basis of just one age we cannot conclusively prove whether the obtained age reflects the true age of the moraine deposition. Considering the stratigraphic position, the moraine could also be older.

The age of sample Fellital 2 is clearly too young. Most likely, this boulder was still covered by moraine material during the early phase of the Holocene. The very steep inner side of the moraine seems to be the result of the active erosion of the Fellibach (Felli creek). Over-steepening might have led to lateral erosion and finally to a lowering and shift of what now appears to be the moraine crest. The boulder was, thus, most probably exhumed.

\section{Discussion}

Human activity, natural depositional and erosional processes, and weathering play a crucial role for the preservation of glacial landforms and the apparent ages of exposure-dated rock surfaces (e.g., Gosse and Philips, 2001). The paucity of well-preserved moraines and/or datable boulders on and organic remnants in such landforms have so far hampered the introduction of a trustworthy early to middle Lateglacial chronology of the glacier development in the Swiss Alps. Although we cannot establish a conclusive chronology of the glacial history of the lower Reusstal, our obtained dating results give important hints about the Lateglacial glacier development in the Reusstal, while at the same time pointing out the difficulties in the research field.

The evolution of the Reussgletscher directly after the LGM was addressed in an exposure-dating study by Reber et al. (2014): they inferred a minimum age of $22.2 \pm 1.0 \mathrm{ka}$ for the retreat from the frontal position in the Swiss foreland (Lenzburg, canton of Aargau) and a potentially synchronous retreat from a high lateral Alpine border position at the Seeboden moraine (Rigi, canton Schwyz; minimum age of $20.4 \pm 1.0 \mathrm{ka}$ ). A moraine of the subsequent Stetten stadial at Wohlen (canton of Aargau), approximately $12 \mathrm{~km}$ behind the LGM extent, was dated to $18.6 \pm 0.9 \mathrm{ka}$. For the following early Lateglacial period a general phase of rapid ice decay with glaciers no longer responding to climate signals has been suggested (Schlüchter, 1988; Reitner, 2007). To what extent this concept can also be applied to the Reussgletscher catchment and the observed lateral moraines in the area of the Schattdorfer Berge and potentially linked terminal positions on the bottom of Lake Lucerne cannot be clarified within the context of this study. High-resolution bathymetric data suggest a succession of at least four partly very pronounced moraines, protected from subaerial erosion, at the bottom of Lake Lucerne (Hilbe et al., 2011). Considering complex ice dynamics as another potential explanation for the moraine deposition, Hilbe et al. (2016) interpreted two of the observed moraines (Nase and Chindli) as recessional moraines deposited by climate-driven stillstands or readvances that interrupted the general ice retreat. Our attempts to date the potentially related lateral moraines in the area of the Schattdorfer Berge were unsuccessful, because the obtained ages are far too young compared to the given stratigraphic position of the sampled boulders. An age attribution to these early Lateglacial stadials is, thus, at the moment not possible.

Following these stages, the Reussgletscher retreated further to the south towards the main Alpine chain. Morphological evidence suggests a next re-advance or stillstand of the Reussgletscher in the area of Attinghausen. Due to a lack of suitable samples, the Attinghausen stage could not be conclusively dated. But minimum ages for this glacier extent could be inferred from the bedrock sample Erstfeld Sackberg $(13200 \pm 1910 \mathrm{a})$ and from the outer lateral moraine in the Arnisee area, indicating a connection to the Reussgletscher occupying the main valley. Although this lateral moraine yielded apparently too-young exposure ages, the radiocarbon age of the adjacent peat bog revealed that the glacier, which deposited this moraine, must have vanished before $15108-$ 14416 cal a BP. Since this bog could only develop after the ice had disappeared from the area, the onset of the bog accretion corresponds to a minimum age for the neighboring lateral moraine. Accordingly, we can infer that the Attinghausen stage must be older than the Bølling-Allerød interstadial $(>14.6 \mathrm{ka})$. Based on the regional stratigraphic succession, re-advances of a small glacier northwest of Erstfeld Sackberg and of the Hoch Fulen-Bälmeten glacier in the area of the Schattdorfer Berge can most likely also be attributed to the Attinghausen stage. In a former study without absolute age data it was postulated that the Attinghausen stage (Renner in Spillmann et al., 2011) would be the local equivalent of the Gschnitz stadial of the East Alpine deglaciation system. This stadial was defined at the Gschnitz type locality at Trins in Tyrol, Austria (Penck and Brückner, 1909; Heuberger, 1966), and later dated to 17-16 ka (Ivy-Ochs et al., 2006; Ivy-Ochs, 2015). Due to a lack of suitable sites, so far only very few presumptive Gschnitz-equivalent moraines have been dated in the Alps (Ivy-Ochs et al., 2008; Federici et al., 2011). But paleobotanical and diatom-based evidence from the Längsee, Austria, also suggests the existence of a related cold interval from 17.6 to 16.9 cal ka BP (Huber et al., 2010; Schmidt et al., 2012). The Alpine-wide correlation of type localities without conclusive absolute dating results has recently been criticized since it often leads to erroneous ideas of the local glacier development (Reitner et al., 2016; Boxleitner, unpublished data). Our inferred minimum age $(>14.6 \mathrm{ka}$ ) does not allow for a final age definition of the Attinghausen stage. Assuming that the Attinghausen stage was deposited around 17-16 ka, this would suggest 
that there might have been, at least regionally, pronounced glacier re-advances after the LGM that are older than the Gschnitz stadial as evidenced by the moraines in the area of the Schattdorfer Berge and related terminal positions in Lake Lucerne. However, more studies would be necessary to address these early Lateglacial moraine sequences in detail.

Further re-advances of the Reussgletscher with end positions on the main valley floor between Attinghausen and the mouth of the Fellital either never took place or have not been preserved. The study site Leitschach-Arnisee contains indication for both a glaciation of the main valley and locally confined glacier re-advances from the Leitschach. On the basis of its position and the inferred minimum age, the outermost moraine can most likely be attributed to the Attinghausen stage despite the inaccuracy of the obtained exposure ages. From the set of local re-advance moraines, the oldest could be dated. As the two moraine constellations imply completely different glacier dimensions, a pronounced age gap between them could be expected. This, however, is not reflected in our dating results. The exposure ages from the outermost local moraine could indicate a pre-Allerød age (mean: 13840 a). But if we consider the two exposure ages separately, a deposition of the moraine during the early YD or even before the Bølling-Allerød interstadial cannot be excluded. From the location of these moraines we can infer that the ice volume of the Reussgletscher was definitely diminished during this stage. It remains unclear if unconnected ice on the valley floor was still present or if the Reusstal was already widely ice free.

Up-valley, there is clear morphological evidence for a re-advance of the Fellitalgletscher to the junction with the Reusstal. Here, based on the relative position of the moraines, the local glacier advance must have occurred after the retreat of the Reussgletscher from the main valley. One of the exposure ages from the Fellital site suggests that the moraines were deposited at the end of the Younger Dryas. In the light of an YD-aged glacier terminal position at the transition of the Göschenertal to the Reusstal (Boxleitner et al., 2017), this age attribution appears plausible but cannot be definitely proven on the basis of one single exposure age.

\section{Conclusions}

Our knowledge about the Alpine glacier development between the Last Glacial Maximum and the Younger Dryas is still very limited. In a local study within the Reussgletscher catchment in central Switzerland we therefore addressed moraines and other glacier-related landforms that were supposedly deposited prior to the YD by means of ${ }^{10} \mathrm{Be}$ exposure and radiocarbon dating.

Although we have indication for moraine deposition clearly predating the Younger Dryas, a conclusive chronology of the glacier development remains a challenge.
The depositional age of the stratigraphically oldest lateral moraines in the area of the Schattdorfer Berge remains unclear. Corresponding terminal positions of the Reussgletscher have been described on the bottom of Lake Lucerne. Although undated, the existence of this moraine sequence seems to be inconsistent with the postulated phase of rapid ice decay following the end of the last ice age.

The next, stratigraphically younger unit is the Attinghausen stage, for which we could infer a minimum age prior to the Bølling-Allerød interstadial (>14.6 ka). Presumably parallel glacier advances in the area of the Schattdorfer Berge could potentially be dated with ${ }^{36} \mathrm{Cl}$ exposure dating (limestone).

A subsequent local glacier re-advance from the side valley Leitschach can be roughly attributed to the time interval before the Bølling-Allerød interstadial and the early Younger Dryas, which includes different cold events as potential triggers.

The stratigraphically youngest moraines in the study area, indicating a local glacier advance from the Fellital to an icefree main valley, can likely be attributed to the YD.

The investigation of the glacier development during the early and middle Lateglacial is very challenging, mostly because related landforms and datable boulders suitable for cosmogenic nuclide dating are rare and because methodological and geological uncertainties complicate the interpretation of the derived ages. Nevertheless, knowing the timing and extent of paleoglaciers during this period is important for our understanding of the late Quaternary history of the Alps in the context of regional and global climate patterns. The identification of further key sites is therefore essential to compile a conclusive chronology of the Alpine Lateglacial.

Data availability. The input data for the calculation of the exposure ages are available in the Supplement.

Supplement. The supplement related to this article is available online at: https://doi.org/10.5194/gh-73-241-2018-supplement.

Competing interests. The authors declare that they have no conflict of interest.

Acknowledgements. We would like to thank Gerald Raab, Ulrich Hanke and Tobias Francke for hearty support during fieldwork.

We are also grateful to two anonymous reviewers for their constructive comments, which appreciably improved the manuscript. Special thanks go to the geochronology group of the Geography Department of the University of Zurich (Thomy Keller and Gerald Raab) and the ETH Laboratory of Ion Beam Physics. Also, we would like to thank Felix Renner for his support during our sampling campaigns. The meteorological data were provided by the Swiss Federal Office of Meteorology and Climatology 
(MeteoSwiss).

Edited by: Isabelle Gärtner-Roer

Reviewed by: two anonymous referees

\section{References}

Akçar, N., Ivy-Ochs, S., Kubik, P. W., and Schlüchter, C.: Postdepositional impacts on "Findlinge" (erratic boulders) and their implications for surface-exposure dating, Swiss J. Geosci., 104, 445-453, https://doi.org/10.1007/s00015-011-0088-7, 2011.

André, M.: Rates of postglacial rock weathering on glacially scoured outcrops (abisko-riksgränsen area, $68^{\circ} \mathrm{n}$ ), Geogr. Ann. A, 84, 139-150, https://doi.org/10.1111/j.04353676.2002.00168.x, 2002.

Balco, G., Stone, J. O., Lifton, N. A., and Dunai, T. J.: A complete and easily accessible means of calculating surface exposure ages or erosion rates from ${ }^{10} \mathrm{Be}$ and ${ }^{26} \mathrm{Al}$ measurements, Quat. Geochronol., 3, 174-195, https://doi.org/10.1016/j.quageo.2007.12.001, 2008.

Balco, G., Briner, J., Finkel, R. C., Rayburn, J. A., Ridge, J. C., and Schaefer, J. M.: Regional beryllium10 production rate calibration for late-glacial northeastern North America, Quat. Geochronol., 4, 93-107, https://doi.org/10.1016/j.quageo.2008.09.001, 2009.

Borchers, B., Marrero, S., Balco, G., Caffee, M., Goehring, B., Lifton, N., Nishiizumi, K., Phillips, F., Schaefer, J., and Stone, J.: Geological calibration of spallation production rates in the CRONUS-Earth project, Quat. Geochronol., 31, 188-198, https://doi.org/10.1016/j.quageo.2015.01.009, 2016.

Boxleitner, M., Musso, A., Waroszewski, J., Malkiewicz, M., Maisch, M., Dahms, D., Brandová, D., Christl, M., de Castro Portes, R., and Egli, M.: Late Pleistocene Holocene surface processes and landscape evolution in the central Swiss Alps, Geomorphology, 295, 306-322, https://doi.org/10.1016/j.geomorph.2017.07.006, 2017.

Bronk Ramsey, C.: Bayesian analysis of radiocarbon dates, Radiocarbon, 51, 337-360, https://doi.org/10.1017/S0033822200033865, 2009.

Chmeleff, J., von Blanckenburg, F., Kossert, K., and Jakob, D.: Determination of the ${ }^{10} \mathrm{Be}$ half-life by multicollector ICP-MS and liquid scintillation counting, Nuclear Instruments and Methods in Physics Research Section B: Beam Interactions with Materials and Atoms, 268, 192-199, https://doi.org/10.1016/j.nimb.2009.09.012, 2010.

Christl, M., Vockenhuber, C., Kubik, P. W., Wacker, L., Lachner, J., Alfimov, V., and Synal, H.-A.: The ETH Zurich AMS facilities: Performance parameters and reference materials, Nuclear Instruments and Methods in Physics Research Section B: Beam Interactions with Materials and Atoms, 294, 29-38, https://doi.org/10.1016/j.nimb.2012.03.004, 2013.

Claude, A., Ivy-Ochs, S., Kober, F., Antognini, M., Salcher, B., and Kubik, P.: The Chironico landslide (Valle Leventina, southern Swiss Alps): age and evolution, Swiss J. Geosci., 107, 273-291, https://doi.org/10.1007/s00015-014-0170-z, 2014.

Delunel, R., Bourlès, D. L., van der Beek, P. A., Schlunegger, F., Leya, I., Masarik, J., and Paquet, E.: Snow shielding factors for cosmogenic nuclide dating inferred from long-term neutron detector monitoring, Quat. Geochronol., 24, 16-26, https://doi.org/10.1016/j.quageo.2014.07.003, 2014.

Federici, P. R., Granger, D. E., Ribolini, A., Spagnolo, M., Pappalardo, M., and Cyr, A. J.: Last Glacial Maximum and the Gschnitz stadial in the Maritime Alps according to ${ }^{10} \mathrm{Be}$ cosmogenic dating, Boreas, 41, 277-291, https://doi.org/10.1111/j.1502-3885.2011.00233.x, 2011.

Gosse, J. C. and Phillips, F. M.: Terrestrial in situ cosmogenic nuclides: theory and application, Quaternary Sci. Rev., 20, 14751560, https://doi.org/10.1016/S0277-3791(00)00171-2, 2001.

Hantke, R.: Eiszeitalter, Bd. 2. Die jüngste Erdgeschichte der Schweiz und ihrer Nachbargebiete, Ott. Verlag., 1980.

Heuberger, H.: Gletschergeschichtliche Untersuchungen in den Zentralalpen zwischen Sellrain-und Ötztal, Universitätsverlag Wagner, Innsbruck, 1966.

Heyman, J.: Paleoglaciation of the Tibetan Plateau and surrounding mountains based on exposure ages and ELA depression estimates, Quaternary Sci. Rev., 91, 30-41, https://doi.org/10.1016/j.quascirev.2014.03.018, 2014.

Hilbe, M., Anselmetti, F. S., Eilertsen, R. S., Hansen, L., and Wildi, W.: Subaqueous morphology of Lake Lucerne (Central Switzerland): implications for mass movements and glacial history, Swiss J. Geosci., 104, 425-443, https://doi.org/10.1007/s00015011-0083-z, 2011.

Hilbe, M., Strupler, M., Hansen, L., Eilertsen, R. S., Van Daele, M., De Batist, M., and Anselmetti, F. S.: Moraine ridges in fjord-type, perialpine Lake Lucerne, central Switzerland, Geological Society, London, Memoirs, 46, 69, https://doi.org/10.1144/M46.107, 2016.

Huber, K., Weckström, K., Drescher-Schneider, R., Knoll, J., Schmidt, J., and Schmidt, R.: Climate changes during the last glacial termination inferred from diatom-based temperatures and pollen in a sediment core from Längsee (Austria), J. Paleolimnol., 43, 131-147 https://doi.org/10.1007/s10933-009-9322y, 2010.

Ivy-Ochs, S.: Glacier variations in the European Alps at the end of the last glaciation, Cuadernos de investigación geográfica, 41, 295-315, https://doi.org/10.18172/cig.2750, 2015.

Ivy-Ochs, S. and Kober, F.: Surface exposure dating with cosmogenic nuclides, Quaternary Sci. J., 57, 157-189, https://doi.org/10.1002/jqs.1202, 2008.

Ivy-Ochs, S., Schlüchter, C., Kubik, P. W., Synal, H.-A., Beer, J., and Kerschner, H.: The exposure age of an Egesen moraine at Julier Pass, Switzerland, measured with the cosmogenic radionuclides ${ }^{10} \mathrm{Be},{ }^{26} \mathrm{Al}$ and ${ }^{36} \mathrm{Cl}$, Eclogae Geol. Helv., 89, 1049-1064, 1996.

Ivy-Ochs, S., Kerschner, H., Kubik, P. W., and Schlüchter, C.: Glacier response in the European Alps to Heinrich Event 1 cooling: the Gschnitz stadial, J. Quaternary Sci., 21, 115-130, https://doi.org/10.1002/jqs.955, 2006.

Ivy-Ochs, S., Kerschner, H., and Schlüchter, C.: Cosmogenic nuclides and the dating of Lateglacial and Early Holocene glacier variations: The Alpine perspective, Quatern. Int., 164-165, 5363, https://doi.org/10.1016/j.quaint.2006.12.008, 2007.

Ivy-Ochs, S., Kerschner, H., Reuther, A., Preusser, F., Heine, K., Maisch, M., Kubik, P. W., and Schlüchter, C.: Chronology of the last glacial cycle in the European Alps, J. Quaternary Sci., 23, 559-573, 2008. 
Ivy-Ochs, S., Kerschner, H., Maisch, M., Christl, M., Kubik, P. W., and Schlüchter, C.: Latest Pleistocene and Holocene glacier variations in the European Alps, Quaternary Sci. Rev., 28, $2137-$ 2149, https://doi.org/10.1016/j.quascirev.2009.03.009, 2009.

Kohl, C. and Nishiizumi, K.: Chemical isolation of quartz for measurement of in-situ-produced cosmogenic nuclides, Geochim. Cosmochim. Ac., 56, 3583-3587, https://doi.org/10.1016/00167037(92)90401-4, 1992.

Korschinek, G., Bergmaier, A., Faestermann, T., Gerstmann, U. C., Knie, K., Rugel, G., Wallner, A., Dillmann, I., Dollinger, G., and Von Gostomski, C. L.: A new value for the half-life of ${ }^{10} \mathrm{Be}$ by heavy-ion elastic recoil detection and liquid scintillation counting, Nuclear Instruments and Methods in Physics Research Section B: Beam Interactions with Materials and Atoms, 268, 187191, https://doi.org/10.1016/j.nimb.2009.09.020, 2010.

Kubik, P. W. and Christl, M.: ${ }^{10} \mathrm{Be}$ and ${ }^{26} \mathrm{Al}$ measurements at the Zurich $6 \mathrm{MV}$ Tandem AMS facility, Nuclear Instruments and Methods in Physics Research Section B: Beam Interactions with Materials and Atoms, 268, 880-883, https://doi.org/10.1016/j.nimb.2009.10.054, 2010.

Labhart, T. and Pfiffner, O. A.: Geologische Karte des Kantons Uri 1:100 000, Geologie des Kantons Uri, NGU Bericht Nr. 24, 2011 : Beilage 1, GRENZEN - Digitale Kartografie Andreas Baumeler, Zürich; in: Geologie des Kantons Uri, edited by: Spillmann, P., Labhart, T., Brückner, W., Renner, F., Gisler, C., and Zgraggen, A., Naturforschende Gesellschaft Uri, 2011.

Lal, D.: Cosmic ray labeling of erosion surfaces: in situ nuclide production rates and erosion models, Earth Planet. Sc. Lett., 104, 424-439, https://doi.org/10.1016/0012-821X(91)90220-C, 1991.

Moran, A. P., Ivy-Ochs, S., Schuh, M., Christl, M., and Kerschner, H.: Evidence of central Alpine glacier advances during the Younger Dryas-early Holocene transition period, Boreas, 45, 398-410, https://doi.org/10.1111/bor.12170, 2016.

Nishiizumi, K., Imamura, M., Caffee, M. W., Southon, J. R., Finkel, R. C., and McAninch, J.: Absolute calibration of ${ }^{10} \mathrm{Be}$ AMS standards, Nuclear Instruments and Methods in Physics Research Section B: Beam Interactions with Materials and Atoms, 258, 403-413, https://doi.org/10.1016/j.nimb.2007.01.297, 2007.

Penck, A. and Brückner, E.: Die Alpen im Eiszeitalter, 1199 S, Tauchnitz, Leipzig, 1909.

Putkonen, J. and Swanson, T.: Accuracy of cosmogenic ages for moraines, Quaternary Res., 59, 255-261, https://doi.org/10.1016/S0033-5894(03)00006-1, 2003.

Reber, R., Akçar, N., Ivy-Ochs, S., Tikhomirov, D., Burkhalter, R., Zahno, C., Lüthold, A., Kubik, P. W., Vockenhuber, C., and Schlüchter, C.: Timing of retreat of the Reuss Glacier (Switzerland) at the end of the Last Glacial Maximum, Swiss J. Geosci., 107, 293-307, https://doi.org/10.1007/s00015-0140169-5, 2014.

Reimer, P. J., Bard, E., Bayliss, A., Beck, J. W., Blackwell, P. G., Ramsey, C. B., Buck, C. E., Cheng, H., Edwards, R. L., Friedrich, M., Grootes, P. M., Guilderson, T. P., Haflidason, H., Hajdas, I., Hatté, C., Heaton, T. J., Hoffmann, D. L., Hogg, A. G., Hughen, K. A., Kaiser, K. F., Kromer, B., Manning, S. W., Niu, M., Reimer, R. W., Richards, D. A., Scott, E. M., Southon, J. R., Staff, R. A., Turney, C. S. M., and van der Plicht, J.: IntCal13 and Marine13 Radiocarbon Age Calibration
Curves 0-50,000 Years cal BP, Radiocarbon, 55, 1869-1887, https://doi.org/10.2458/azu_js_rc.55.16947, 2013.

Reitner, J., Ivy-Ochs, S., Drescher-Schneider, R., Hajdas, I., and Linner, M.: Reconsidering the current stratigraphy of the Alpine Lateglacial: Implications of the sedimentary and morphological record of the Lienz area (Tyrol/Austria), E\&G Quaternary Sci. J., 65, 113-144, https://doi.org/10.3285/eg.65.2.02, 2016.

Reitner, J. M.: Glacial dynamics at the beginning of Termination $\mathrm{I}$ in the Eastern Alps and their stratigraphic implications, Quatern. Int., 164-165, 64-84, https://doi.org/10.1016/j.quaint.2006.12.016, 2007.

Renner, F. B.: Beiträge zur Gletschergeschichte des Gotthardgebietes und dendroklimatologische Analysen an fossilen Hölzern, Universität Zürich, 1982.

Reuther, A., Ivy-Ochs, S., and Heine, K.: Application of surface exposure dating in glacial geomorphology and the interpretation of moraine ages, Z. Geomorphol. Supp., 142, 335-359, 2006.

Schimmelpfennig, I., Schaefer, J. M., Akçar, N., Ivy-Ochs, S., Finkel, R. C., and Schlüchter, C.: Holocene glacier culminations in the Western Alps and their hemispheric relevance, Geology, 40, 891-894, https://doi.org/10.1130/G33169.1, 2012.

Schindelwig, I., Akçar, N., Kubik, P. W., and Schlüchter, C.: Lateglacial and early Holocene dynamics of adjacent valley glaciers in the Western Swiss Alps, J. Quaternary Sci., 27, 114124, https://doi.org/10.1002/jqs.1523, 2012.

Schlüchter, C.: The deglaciation of the Swiss-Alps: a paleoclimatic event with chronological problems, Bulletin de l'Association Francaise pour l'étude du Quaternaire, 25, 141-145, 1988.

Schmidt, R., Weckström, K., Lauterbach, S., Tessadri, R., and Huber, K.: North Atlantic climate impact on early late-glacial climate oscillations in the south-eastern Alps inferred from a multi-proxy lake sediment record, J. Quaternary Sci., 27, 40-50, https://doi.org/10.1002/jqs.1505, 2012.

Spillmann, P., Labhart, T., Brückner, W., Renner, F., Gisler, C., and Zgraggen, A.: Geologie des Kantons Uri, Naturforschende Gesellschaft Uri, 2011.

Stone, J. O.: Air pressure and cosmogenic isotope production, J. Geophys. Res.-Sol. Ea., 105, 23753-23759, https://doi.org/10.1029/2000JB900181, 2000.

von Blanckenburg, F., Belshaw, N. S., and O’Nions, R. K.: Separation of ${ }^{9} \mathrm{Be}$ and cosmogenic ${ }^{10} \mathrm{Be}$ from environmental materials and SIMS isotope dilution analysis, Chem. Geol., 129, 93-99, https://doi.org/10.1016/0009-2541(95)00157-3, 1996.

Zweck, C., Zreda, M., and Desilets, D.: Snow shielding factors for cosmogenic nuclide dating inferred from Monte Carlo neutron transport simulations, Earth Planet. Sci. Lett., 379, 64-71, https://doi.org/10.1016/j.epsl.2013.07.023, 2013. 